\title{
MEDIA KOMUNIKASI DAN INFORMASI DALAM MENUNJANG KEGIATAN PENYULUHAN PERTANIAN
}

\author{
Ida Ruyadi ${ }^{1}$, Yunus Winoto ${ }^{2}$, Neneng Komariah ${ }^{3}$ \\ ${ }^{1}$ BPTP Papua Barat (Badan Litbang Pertanian), ${ }^{2,3}$ Universitas Padjadjaran \\ idaruyadi@pertanian.go.id ${ }^{1}$, yunus.winoto@unpad.ac.id ${ }^{2}$, neneng.komariah@unpad.ac.id ${ }^{3}$
}

\begin{abstract}
This study is to investigate the use of information and communication media in supporting agricultural extension activities. Media communication in this study is limited to brochures and leaflets. Research conducted at the Institute for Agricultural Technology in West Java. The population in this study is the agricultural extension workers with a total sample of 48 people. The method used is descriptive method with data collection through questionnaires, interviews, observations, and literature. Based on the results showed that: Frequency of use of com-munication media such as brochures and leaflets by agricultural extension workers are not too high, but most respondents using brochures and leaflets as a medium supporting agricultural extension activities; The intensity of the use of brochures and leaflets by agricultural extension is also not too high, but almost half of the respondents use of brochures and leaflets in supporting agricultural extension activities; The reason the use of brochures and leaflets in general respondents stated that because of the information contained in brochures and leaflets in accordance with the needs in supporting agricultural extension activities; While the purpose of the use of brochures and leaflets majority of respondents stated to increase knowledge in supporting agricultural extension activities.
\end{abstract}

Keywords: agricultural extension, agricultural communication media, brochures, leaflets

ABSTRAK - Penelitian ini adalah untuk mengetahui penggunaan media komunikasi dan informasi dalam menunjang kegiatan penyuluhan pertanian. Media komunikasi dalam penelitian ini dibatasi pada media brosur dan leaflet. Penelitian dilaksanakan di Balai Pengkajian Teknologi Pertanian Jawa Barat. Populasi dalam penelitian ini adalah para penyuluh pertanian dengan jumlah sampel sebanyak 48 orang. Metode penelitian yang digunakan adalah metode deskrptif dengan teknik pengumpulan data melalui angket, wawancara, observasi serta studi pustaka. Berdasarkan hasil penelitian menunjukan bahwa: Frekuensi peng- gunaan media komunikasi yang berupa brosur dan leaflet oleh petugas penyuluh pertanian tidak terlalu tinggi, namun sebagian besar responden menggunakan brosur dan leaflet sebagai media penunjang kegiatan penyuluhan pertanian; Intensitas penggunaan brosur dan leaflet oleh penyuluh pertanian juga tidak terlalu tinggi namun hampir setengah dari responden menggunakan brosur dan leaflet dalam menunjang kegiatan penyuluhan pertanian; Alasan pemanfaatan brosur dan leaflet pada umumnya responden menyatakan karena informasi yang terkandung dalam brosur dan leaflet sesuai dengan kebutuhan dalam menunjang kegiatan penyuluhan pertanian; Se- dangkan tujuan penggunaan brosur dan leaflet sebagian besar responden menyatakan untuk menambah pengetahuan dalam menunjang kegiatan penyuluhan pertanian.

Kata Kunci: penyuluhan pertanian, media komunikasi pertanian, brosur, leaflet

\section{PENDAHULUAN}

Era reformasi dan kebijakan otonomi daerah telah mendorong reorientasi pembangunan pertanian dari pendekatan yang berbasis sumberdaya menjadi pendekatan yang berbasis masyarakat (community based development). Sulaiman, (2000) mengatakan bahwa salah satu ciri pembangunan pertanian berbasis masyarakat adalah berorientasi pada partisipasi masyarakat. Sejalan dengan era reformasi dan kebijakan otonomi daerah, berdasarkan Surat Keputusan Menteri Pertanian Republik Indonesia Nomor 798/Kpts/OT.210/12/94 di beberapa daerah dibentuk lembaga Balai Pengkajian Teknologi Pertanian (BPTP). Tujuan pembentukan BPTP selain untuk desentralisasi dalam bidang penelitian dan pengkajian teknologi pertanian 
spesifik lokasi, juga untuk mendekatkan pelayanan pengkajian dan diseminasi informasi kepada masyarakat serta menjaga kesinambungan pengkajian dan penyuluhan pertanian spesifik lokasi. (BPTP Jawa Barat, 2005).

Dalam konteks pembangunan pertanian kegiatan penelitian dan penyuluhan pertanian memegang peranan penting dan tidak dapat dipisahkan antara kegiatan yang satu dengan lainnya, karena kedua kegiatan tersebut pada akhirnya akan bermuara pada tujuan yang sama yaitu meningkatkan kesejahteraan petani. Syam dan Widjono (1992) mengatakan kegiatan penelitian dan penyuluhan pertanian memegang peranan penting dalam mendukung pembangunan pertanian karena sebagian besar upaya untuk meningkatkan produktivitas dan pendapatan petani tergantung kepada kedua kegiatan tersebut.

Kegiatan penelitian/pengkajian pertanian menghasilkan informasi teknologi pertanian/ inovasi teknologi pertanian untuk disampaikan kepada petani melalui penyuluhan pertanian. Selain itu juga kegiatan penelitian/pengkajian teknologi pertanian akan berdaya guna dan berhasil guna apabila teknologi hasil penelitian/ pengkajian tersebut dapat dirasakan manfaatnya oleh masyarakat. Sejalan dengan hal tersebut Balai Pengkajian Teknologi Pertanian Jawa Barat sebagai salah satu Unit Pelaksana Teknis Badan Litbang Pertanian yang berada di daerah telah banyak menghasilkan luaran yang cukup dibutuhkan oleh pengguna/stakeholder untuk peningkatan pembangunan pertanian di daerah, namun luaran /hasil penelitian dan pengkajian yang berkualitas tinggi tersebut tidak akan banyak manfaatnya jika tidak dikomunikasikan dan didiseminasikan. Diseminasi hasil penelitian pertanian kepada petani-nelayan, pihak swasta dan pengguna lain perlu dilakukan melalui metoda dan media yang tepat dan terus menerus, karena kegiatan iseminasi bukan sekedar penyebarluasan informasi dan teknologi pertanian, tetapi lebih dari itu petani-nelayan diharapkan dapat menerapkan hasil penelitian tersebut dalam usaha pertanian sehingga meningkatkan kesejahteraannya (Badan Litbang Pertanian, 2004).

Dalam upaya menyebarluaskan informasi hasil penelitian dan pengkajian teknologi pertanian, BPTP Jawa Barat menerbitkan berbagai jenis media komunikasi dan informasi teknologi pertanian baik yang bersifat ilmiah seperti prosiding maupun ilmiah popular diantaranya adalah brosur dan leaflet. Sasaran utama pengguna media informasi brosur dan leaflet adalah penyuluh pertanian, sehingga informasinya disajikan dan dikemas dengan menggunakan bahasa ilmiah popular agar mudah dipahami dan dapat digunakan sebagai materi penyuluhan. Tjitropranoto, (1989) dalam Suryantini, (2003) mengelompokan informasi hasil penelitian menjadi lima) (5) jenis yakni sebagai berikut:

1) Informasi yang berupa bahan penentuan kebijakan,

2) Informasi hasil penelitian yang memerlukan pengujian lebih lanjut

3) Informasi ilmiah untuk pengembangan iptek

4) Informasi teknologi sarana produksi, serta

5) Informasi teknis untuk materi penyuluhan. 
Litbang Pertanian, (2001) dalam Mindarti et al. (2005) menjelaskan bahw pemanfaatan media komunikasi dan informasi berbentuk brosur dan leaflet dalam kegiatan diseminasi informasi memiliki kelebihan karena dapat menjangkau sasaran yang lebih banyak dan tersebar jauh jika dibandingkan dengan komunikasi tatap muka. Selain itu media cetak bisa dibaca berulang kali, sehingga memudahkan pengguna untuk memahami informasi yang dikandungnya. Namun disisi lain media cetak terkadang tidak efektif mencapai sasaran karena bentuk penyajiannya tidak sesuai dengan karakteristik pengguna yang dituju, misalnya informasi untuk petani disajikan menggunakan bahasa ilmiah. Dapat juga media cetak menjadi tidak bermanfaat karena topik yang disajikan tidak sesuai dengan kebutuhan pengguna, dan lain sebagainya. Berdasarkan hal tersebut diatas maka media cetak brosur dan leaflet agar dapat dimanfaatkan oleh pengguna (penyuluh pertanian) harus disusun berdasarkan kebutuhan informasi pengguna dengan cara mengidentifikasi kebutuhan informasi khalayak yang menjadi sasaran/target group.

Dalam pelaksanaan tugas di lapangan penyuluh pertanian membutuhkan informasi hasil penelitian pertanian yang relevan dengan permasalahan yang ada di lapangan. Hal ini sesuai dengan pendapat Syam dan Widjono dalam Kushartanti, (2001) bahwa informasi/ teknologi pertanian hasil penelitian yang akan dijadikan materi penyuluhan pertanian hendaknya yang relevan dengan permasalahan yang dihadapi oleh petani. Stepanus, (1972) dalam Mulyani et al.
(2006) menyatakan bahwa tingkat pemanfaatan suatu media ditentukan oleh karakteristik pembacanya, antara lain pendidikan, pekerjaan, penghasilan, partisipasi dalam organisasi, kefanatikan, dan kekosmopolitan. Masih dalam sumber yang sama Rhaza dan Moriaty (1970) menyatakan bahwa pemanfaatan suatu media dipengaruhi oleh tingkat pengetahuan dan pengalaman kerja. Sedangkan Asopa ( 1997) dalam Sulaiman (2000) mengatakan bahwa rekomendasi teknologi yang tidak pas dengan pengetahuan dan bahasa petani kemungkinan besar tidak akan diadopsi oleh petani sebagai pengguna akhir kegiatan diseminasi informasi, oleh karena itu penugasan seorang peneliti untuk pembuatan materi penyuluhan pertanian tidaklah tepat karena peneliti mempunyai bahasa yang berbeda dengan petani, dan masing-masing mempunyai system pengetahuan (knowledge system) yang berbeda. Setiap BPTP membutuhkan staf dengan spesialisasi informasi (information specialist), yang salah satu tugasnya adalah melaksanakan kegiatan komunikasi dan diseminasi informasi hasil penelitian/ pengkajian teknologi pertanian. Dari seluruh tahapan pelaksanaan kegiatan penelitian dan pengkajian tersebut dapat disimpulkan bahwa kegiatan komunikasi dan diseminasi merupakan tahap akhir yang akan menentukan efektivitas institusi BPTP, terutama dalam pandangan pengguna akhir (petani), dan stakeholders (penyuluh pertanian). Sayangnya tahapan akhir yang akan menentukan efektivitas institusi BPTP tersebut belum dapat perhatian yang memadai dari penentu kebijakan. 
Oleh karena demikian berdasarkan uraian tersebut di atas, maka dapat dirumuskan masalah sebagai berikut "Bagaimana penggunaan media komunikasi dan informasi teknologi Pertanian berbentuk brosur dan leaflet dalam menunjang kegiatan penyuluhan pertanian".

Kemudian mengenai tujuan penelitian ini adalah sebagai berikut :

1) Untuk mengetahui frekuensi penggunaan media komunikasi dan informasi teknologi pertanian berbentuk brosur dan leaflet dalam menunjang kegiatan penyuluhan pertanian.

2) Untuk mengetahui intensitas penggunaan media komunikasi dan informasi teknologi pertanian berbentuk brosur dan leaflet dalam menunjang kegiatan penyuluhan pertanian.

3) Untuk mengetahui latarbelakang penggunaan media komunikasi dan informasi teknologi pertanian berbentuk brosur dan leaflet dalam menunjang kegiatan penyuluhan pertanian.

4) Utuk mengetahui tujuan penggunaan media komunikasi dan informasi teknologi pertanian berbentuk brosur dan leaflet dalam menunjang kegiatan penyuluhan pertanian.

\section{TINJAUAN PUSTAKA}

Pertiwi dan Saleh (2010) menyatakan bahwa peningkatan kesejahteraan petani merupakan salah satu tujuan penyuluhan pertanian, yang ditegaskan dalam UU RI No.16 Tahun 2006 bahwa penyuluhan salah satunya ditujukan untuk memberdayakan pelaku utama dan pelaku usaha dalam peningkatan kemampuan melalui penciptaan iklim usaha yang kondusif, penumbuhan motivasi, pengembangan potensi, pemberian peluang, peningkatan kesadaran dan pendampingan serta fasilitasi.

Salah satu upaya yang digunakan dalam kegiatan penyuluhan pertanian adalah penggunaan media komunikasi dan informasi sebagi media perantara informasi pertanian yang akan diberikan kepada para petani. Seperti halnya brosur yang umumnya berisi pesan-pesan yang bersifat informatif, persuasif dan faktual. Maksud dari sifat-sifat tersebut adalah, pesan dalam brosur umumnya memuat informasi yang ingin disampaikan kepada khalayak. Pesan dalam brosur juga memudahkan para pembaca agar dapat dengan mudah tertarik dengan pesan yang disampaikan oleh brosur tersebut (Stefanie, 2013).

Penyebaran informasi melalui penyuluhan dan metode komunikasi lainnya dapat membantu petani memperoleh inovasi dan solusi guna memperbaiki sistem pengelolaan kebun agroforest-nya sehingga dapat meningkatkan pendapatan dan menjaga kelestarian lingkungan (Paramita, Martini, Roshetko \& Finlayson, 2013).

Sebagaimana yang telah dikemukakan sebelumnya penelitian ini mengkaji tentang media komunikasi dan informasi dalam kegiatan penyuluhan. Effendy (1981, 12) mendefinisikan komunikasi sebagai, "Proses dimana seseorang (komunikator) menyampaikan perangsangperangsang (basanya lambang-lambang dalam bentuk kata-kata) untuk merubah tingkah laku 
orang-orang lain (komunikate). Sedangkan mengenai pengertian media komunikasi secara sederhana dapat diartikan sebagai media yang digunakan untuk menyampaikan pesan-pesan komunikasi.

Kemudian mengenai landasan teori yang digunakan dalam penelitian, penulis menggunakan teori difusi inovasi dikembangkan oleh Everett M. Rogers. Menurut Rogers (1983) mendefinisikan difusi sebagai proses dimana suatu inovasi dikomunikasikan melalui saluran tertentu dalam jangka waktu tertentu di antara para anggota suatu sistem sosial. Difusi adalah suatu komunikasi jenis khusus yang yang berkaitan dengan penyebaran pesan-pesan sebagai ide baru. Dalam konteks komunikasi difusi inovasi merupakan bagian khusus yang dari proses komunikasi yang ada disebabkan informasi yang dipertukarkan adalah inovasi. Teori difusi inovasi adalah sebuah model yang menggambarkan aktivitas pertukaran informasi baru yang berlangsung dengan tujuan terjadinya proses adopsi inovasi dalam diri khalayak.

\section{METODE PENELITIAN}

Metode yang dipergunakan dalam penelitian ini adalah metode deskriptif dengan jenis penelitian survey. Adapun yang dimaksud dengan metode deskriptif adalah suatu metode yang berupaya memecahkan atau menjawab permasalahan yang dihadapi dalam situasi sekarang. Sedangkan menurut Yatim Rianto (1996, 21) menyatakan bahwa, "Penelitian deskriptif adalah penelitian yang diarahkan untuk menjelaskan tentang gejala-gejala, fakta-fakta atau kejadian-kejadian secara sistematis, akurat mengenai sifat-sifat populasi atau daerah tertentu". Sedangkan mengenai lokasi dalam penelitian ini dilakukan di Balai Pengkajian Teknologi Pertanian/BPTP Jawa Barat yang beralamat di Jalan Kayu Ambon No. 80 Lembang Bandung.

\section{HASIL DAN PEMBAHASAN}

Penelitian ini mengkaji tentang penggunaan media komunikasi dan informasi dalam kegiatan penyuluhan pertanian. Populasi dalam penelitian ini adalah para penyuluh pertanian yang tersebar di tiga lokasi yakni yakni Lembang, Purwakarta dan Kabupaten Sumedang yang berjumlah 48 orang. Berdasarkan hasil pengolahan data dapat dikemukakan hasil sebagai berikut: Untuk data penelitian ini terdiri dari data responden yakni data yang berkaitan dengan data responden. Adapun berdasarkan hasil penelitian terungkap bahwa dilihat dari jenis kelaminnya responden dalam penelitian sebagian besar adalah laki-laki yakni sebanyak 34 orang (70.83\%) dengan usia responden sebagian besar $79.17 \%$ berusia lebih dari 35 tahun dengan masa kerja pada umumnya lebih dari 10 tahun. Sedangkan jika dilihat dari tingkat pendidikan responden sebagian besar atau sekitar $52.08 \%$ berpendidikan sarjana. Selain memiliki pendidikan formal, responden juga pada umumnya telah mengikuti berbagai pendidikan non formal seperti kegiatan penyuluhan dan pelatihan. Mengenai jabatan fungsional responden kaitannya dengan kegiatan penyuluhan pertanian terdiri dari penyuluh pertanian non kelas, penyuluh pertanian pratama, 
penyuluh pertanian muda serta penyuluh pertanian madya.

Kemudian mengenai hasil pengolahan data penelitian diketahui bahwa media komuniiasi dan informasi yang banyak dimanfaatkan para responden yang ada di tiga lokasi yakni Lembang, Purwakarta dan Kabupaten Sumedang yaitu media brosur dan leaflet. Adapun mengenai frekeunsi pemanfaatan media brosur dan leaflet ini yaitu sekitar 5 kali dalam tiga bulan terakhir. Sedagkan berkaitan dengan intensitas pemanfaatannya dalam setiap kali menggunakan media brosur dan leaflet tersebut yaitu sekitar 1-2 jam.

Ada beberapa hal yang mendorong responden memanfaatkan media komunikasi dan informasi yang berupa brosur dan leaflet yakni petugas penyuluh pertanian selalu dituntut untuk well informed terhadap berbagai perkembangan ilmu pengetahuan dan teknologi maupun informasi lainnya. Oleh karena demikian media komunikasi seperti brosur dan leaflet menurut petugas penyuluh mampu menyajikan informasiinformasi baru yang bisa disampaikan dalam kegiatan penyuluhan.

Selanjutnya mengenai tujuan dari penggunaan media komunikasi dan informasi yang berupa brosur dan leaflet ini oleh responden diantaranya untuk menambah pengetahuan dan wawasan terutama yang berkaitan informasi terbaru, karena dengan diperolehnya informasi baru kegiatan penyuluhan diharapkan bisa berjalan menarik dan sesuai dengan tujuan dari kegiatan penyuyuhan pertanian.

Masih tentang media brosur dan leaflet berdasarkan pendapat responden mengenai kesesuaian informasi yang terdapat dalam brosur maupun leaflet sebagian responden menyatakan informasinya sesuai dengan materi yang dibutuhkan dalam kegiatan penyuluhan. Untuk aspek kemutakhiran dan keakuratan informasinya, menurut sebagian besar responden menyatakan informasi yang terdapat dalam brosur dan leaflet cukup mutakhir serta akurat.

Untuk ketepatan waktu pendistribusian brosur dan leaflet berkaitan dengan pelaksanaan kegiatan penyuluhan yang dilakukan responden sebagian besar responden menyatakan waktu pendistribusiannya sudah tepat sehingga dapat menambah pengayaan responden pada saat melakukan kegiatan penyuluhan . Selain itu juga dengan adanya ketepatan waktu pendistribusian brosur dan leaflet ini akan membantu para penyuluh dalam menyusun program dan materi penyuluhan serta dapat membantu dalam memecahkan masalah yang sering dihadapi dilapangan pada saat melakukan kegiatan.

Dalam mempersiapkan materi dan program penyuluhan selain menggunakan media komunikasi dan informasi yang berupa brosur dan leaflet didistribusikan secara rutin oleh BPTP, para penyuluh juga memanfaatkan media informasi lainnya seperti majalah dan jurnal penelitian, laporan hasil penelitian bidang pertanian, buku teks, surat kabar serta media elektronik maupun media internet. Adapun mengenai jenis informasi yang biasanya dibutuhkan para penyuluh yaitu informasi tentang penentuan kebijakan, pengujian lebih lanjut, pengembangan Iptek di bidang pertanian, sarana produksi maupun informasi tentang teknologi 
lainnya yang dapat menunjang kegiatan penyuluhan.

Sebagaimana yang telah dikemukakan pada halaman sebelumnya, penelitian ini mengkaji tentang penggunaan media komunikasi dalam menunjang para penyuluh di bidang pertanian. Dalam konteks komunikasi yang disebut dengan media adalah merupakan alat atau sarana yang digunakan oleh komunikator dalam menyampaikan pesan komunikasinya. Dalam penelitian ini media komunikasi dan informasi yang diteliti adalah brosur dan leaflet. Adapun mengenai pengertian brosur jika merujuk pada pengetian The ALA Glossary of Library and Information Science. (1983) menyatakan bahwa brosur atau buklet adalah terbitan tidak berkala yang terdiri dari satu hingga sejumlah kecil halaman, tidak terkait dengan terbitanlain, dan selesai dalam sekali terbit. Halamannya sering dijadikan satu biasanya memiliki sampul tapi tidak menggunakan jilid keras. Pengetian lainnya tentang brosur juga dikemukakan oleh UNESCO yang menyebutkan bahwa brosur adalah terbitan tidak berkala yang tidak dijilid keras, lengkap (dalam satu kali terbitan), memiliki paling sedikit 5 halaman tetapi tidak lebih dari 48 halaman, di luar perhitungan sampul. Sedangkan mengenai pengertian leaflet menurut Soedijanto dan Soehardjan (1999) leaflet adalah media cetak yang berbentuk satu lembar kertas lepas dengan ukuran A4 (210 X 297 mm).

Bosur maupun leaflet sebagai media komunikasi memiliki peranan yang sangat penting dalam menunjang keberhasilan suatu proses komunikasi. Hal ini juga ditegaskan oleh Levis,
(1996: 9) menyatakan bahwa faktor-faktor yang menentukan efektivitas keberhasilan komunikasi ditentukan oleh unsur-unsur yang berperan dalam komunikasi diantaranya adalah :

1) Sumber (source) yaitu kemampuan komunikator/penyuluh pertanian atau sumber dalam menyusun tujuan komunikasi, terutama dalam menterjemahkan pesan ke dalam bentuk media, sehingga penerima pesan memiliki sikap positif yang sama terhadap isi pesan atau teknologi yang diberikan. Artinya ada keyakinan bahwa suatu inovasi yang diberikan atau diterima tersebut menguntungkan dan dapat diterima secara sosial.

2) Isi pesan harus utuh dan tidak ada pemenggalan yang dapat membingungkan para penerima atau penguna.

3) Saluran media dipilih berdasarkan pertimbangan ekonomis dan banyak dimanfaatkan pengguna.

Apabila memperhatikan pernyataan Levis di atas, menunjukkan bahwa media atau saluran memiliki kontribusi yang penting dalam menunjang keberhasilan suatu proses komunikasi termasuk dalam hal ini penyuluhan pertanian. Oleh karena demikian seorang tenaga penyuluh pertanian selain harus memiliki keterampilan berkomunikasi juga memiliki pengetahuan yang luas tentang saluran/media komunikasi, sistem sosial, dan budaya yang dimiliki oleh masyarakat yang menjadi sasaran.

Pengertian komunikasi secara umum secara sederhana dapat diartikan sebagai suatu proses penyampaian pesan dari seseorang atau 
sekelompok orang pada orang atau kelompok lainnya dengan tujuan baik untuk memberitahu atau untuk mempengaruhi orang lain. Sedangkan dalam konteks komunikasi pertanian, Soekartawi, (2005: 5) mengartikan komunikasi pertanian adalah suatu pernyataan antar manusia yang berkaitan dengan kegiatan di bidang pertanian, baik secara perorangan maupun secara berkelompok, yang sifatnya umum dengan menggunakan lambang-lambang tertentu seperti sering dijumpai pada metode penyuluhan. Sementara fungsi media komunikasi adalah sebagai alat yang dipakai untuk melakukan komunikasi, sedangkan pelaku komunikasi itu sendiri terdiri dari komunikator dan komunikan melalui pesan yang disampaikan.

Dalam upaya mengkomunikasikan informasi hasil penelitian teknologi pertanian, Badan Penelitian dan Pengembangan Pertanian menerbitkan berbagai jenis media komunikasi dan informasi teknologi pertanian baik yang bersifat ilmiah seperti jurnal ilmiah, prosiding maupun ilmiah popular diantaranya adalah brosur dan leaflet.
Tabel 1

\section{Bentuk dan Isi Pesan Media Brosur dan}

Leaflet

\begin{tabular}{|c|c|c|c|}
\hline No & $\begin{array}{l}\text { Jenis } \\
\text { Media }\end{array}$ & Bentuk & $\begin{array}{l}\text { Isi } \\
\text { pesan/informas }\end{array}$ \\
\hline 1 & Brosur & $\begin{array}{l}\text { a. Tidak } \\
\text { terkait } \\
\text { dengan } \\
\text { terbitan } \\
\text { lain, dan } \\
\text { selesai } \\
\text { dalam } \\
\text { sekali } \\
\text { terbit. } \\
\text { b. Biasanya } \\
\text { memiliki } \\
\text { sam-pul, } \\
\text { tapi tidak } \\
\text { mengguna- } \\
\text { kan jilid } \\
\text { keras. } \\
\text { c. Memiliki } \\
\text { paling } \\
\text { sedikit } 5 \\
\text { halaman } \\
\text { tetapi } \\
\text { tidak } \\
\text { lebih dari } \\
48 \\
\text { halaman, di } \\
\text { luar } \\
\text { perhitunga } \\
\text { n sampul }\end{array}$ & $\begin{array}{l}\text { a.Memuat } \\
\text { informasi } \\
\text { atau } \\
\text { penjelasan } \\
\text { ten-tang } \\
\text { suatu produk, } \\
\text { layanan, } \\
\text { fasilitas } \\
\text { umum, profil } \\
\text { perusa-haan, } \\
\text { sekolah } \\
\text { b.Informasi } \\
\text { dalam brosur } \\
\text { ditulis } \\
\text { dengan } \\
\text { bahasa yang } \\
\text { ringkas, } \\
\text { mudah } \\
\text { dipahami } \\
\text { dalam waktu } \\
\text { singkat. } \\
\text { c.Berisi } \\
\text { informasi } \\
\text { yang } \\
\text { bertujuan } \\
\text { menggugah } \\
\text { sasaran agar } \\
\text { tergerak } \\
\text { hatinya }\end{array}$ \\
\hline
\end{tabular}




\begin{tabular}{|c|c|c|c|}
\hline No & $\begin{array}{l}\text { Jenis } \\
\text { Media }\end{array}$ & Bentuk & $\begin{array}{l}\text { Isi } \\
\text { pesan/informas }\end{array}$ \\
\hline 2 & Leaflet & $\begin{array}{l}\text { a.Berbentuk } \\
\text { satu } \\
\text { lembar } \\
\text { kertas } \\
\text { lepas } \\
\text { dengan } \\
\text { ukuran A4 } \\
\text { (210 } \\
\text { X 297 } \\
\text { mm). } \\
\text { b. Lembar } \\
\text { kertas yang } \\
\text { dilipat, } \\
\text { berisi } \\
\text { informasi } \\
\text { dengan } \\
\text { berbagai } \\
\text { cetakan dan } \\
\text { lay out } \\
\text { yang } \\
\text { menarik } \\
\text { atau berupa } \\
\text { selembar } \\
\text { kertas di } \\
\text { bawah } \\
\text { ukuran A4 } \\
\text { yang } \\
\text { tercetak } \\
\text { satu sisi } \\
\text { atau } \\
\text { keduanya. }\end{array}$ & $\begin{array}{l}\text { a. Leaflet berisi } \\
\text { informasi } \\
\text { teknologi } \\
\text { praktis atau } \\
\text { informasi lain } \\
\text { yang dapat } \\
\text { mendorong } \\
\text { tumbuh-nya } \\
\text { minat sasaran } \\
\text { untuk } \\
\text { mengetahui } \\
\text { lebih lanjut. } \\
\text { b. Leaflet } \\
\text { disusun } \\
\text { ringkas } \\
\text { dengan } \\
\text { bahasa yang } \\
\text { mudah } \\
\text { dipahami } \\
\text { tujuan leaflet } \\
\text { terbatas pada } \\
\text { membangkitk } \\
\text { an motivasi } \\
\text { sasaran } \\
\text {. }\end{array}$ \\
\hline
\end{tabular}

\section{Sumber: Data diolah dari berbagai sumber}

Berbicara lebih jauh tentang media komunikasi, Sudiana (1986) menyebutkan bahwa untuk mencapai tingkat sasaran yang dikehendaki, sebaiknya pesan atau informasi yang akan dikomunikasikan dalam bentuk media brosur dan leaflet harus dipersiapkan secara matang dengan memperhatikan sebagai berikut : (1) Pesan harus direncanakan dan disampaikan dengan gaya penulisan yang menarik; (2) Pesan harus diusahakan dengan pendekatan-pendekatan yang dapat memungkinkan bertemunya pengertian antara komunikator dengan komunikan berdasarkan kesamaan pengalaman;

Diusahakan agar pesan dapat membangkitkan kebutuhan komunikan (pengguna). Selanjutnya Sudiana memberikan gambaran tentang penggunaan ilustrasi, warna dan persiapan grafis sebagai berikut:

\section{1) Faktor Ilustrasi}

Sesuatu yang indah, cantik, lucu, aneh, dan luar biasa adalah hal-hal yang dapat memikat perhatian khalayak, jadi fungsi ilustarsi di sini adalah untuk membina daya tarik. Ilustrasi sering digunakan untuk memudahkan orang mempersepsi pesan yang disampaikan, selain itu ilustrasi juga sering dianggap sebagai bahasa universal yang dapat menembus rintangan yang ditimbulkan oleh perbedaan bahasa. Adapun fungsi ilustrasi dalam pembuatan brosur dan leaflet adalah untuk menarik perhatian, merangsang minat baca keseluruhan pesan, dan mendramatisasi pesan. Soedijanto dan Soehardjan (1999) mengatakan pemberian ilustrasi sebagai penyedap sangat dianjurkan dalam penyusuna media cetak seperti brosur dan leaflet, ilustrasi harus dapat memperjelas isi tulisan dan keterangan ilustarsi dibuat semenarik mungkin. Pemberian nomor, waktu terbit dan nama penyusun dicantumkan pada akhir tulisan. Pemberian nomor diperlukan untuk kepentingan pengelolaan yaitu untuk mempermudah pencarian kembali dan berguna bagi penyusunan perencanaan. 


\section{2) Faktor Warna}

Setiap orang memiliki kesukaan yang berbeda terhadap jenis warna, kecenderungan warna biasanya sangat berhubungan dengan usia, jenis kelamin, dan latar belakang pendidikan. Namun dari hasil tes psikologi mengungkapkan kelompok usia tertentu memiliki kecenderungan warna yang serupa, misalnya warna-warna cerah, menarik perhatian anak-anak muda, warna-warna soft (lembut) bagi orang yang lebih dewasa dan bagi mereka yang berpendidikan lebih tinggi. Pemilihan warna dalam media cetak brosur dan leaflet sebaiknya menerapkan warna secara alamiah bagi tujuan komunikasi, seperti untuk identifikasi, menarik perhatian, menimbulkan pengaruh psikologis, membangun ketahanan minat, dan menciptakan susana yang menye-nangkan. Senada dengan hal ini Effendy (1993) menyatakan bahwa dalam pengaturan warna ialah apabila pesan yang dikomunikasikan diberi ilustrasi barang yang terkandung oleh pesan bersangkutan, warna untuk ilustrasi barang yang dipromosikan harus sama dengan warna barang aslinya.

\section{3) Persiapan Grafis}

Pada tahap persiapan grafis ada tiga hal yang harus dilakukan yaitu menyusun naskah, penyuntingan ilustrasi, dan mengatur tata letak atau layout. Ketiga langkah tersebut didasarkan pada desain yang dibuat pada tahap perencanaan.

Apabila dalam uraian di atas telah dikemukakan tentang sarana atau media komunikasi dalam menunjang kegiatan penyuluhan pertanian, maka ada baiknya dijelaskan pula tentang konsep penyuluh itu sendiri. Adapun jika dilihat dari asal usul katanya kata penyuluh berasal dari kata suluh yang artinya obor, atau benda yang dipakai untuk menerangi. Masih tentang penyuluhan Nasution, (1996:11) mengartikan penyuluhan adalah sebagai suatu usaha pendidikan non formal dengan maksud mengajak orang sadar dan mau melaksanakan ide-ide baru. Penyuluhan pada hakekatnya merupakan suatu langkah dalam usaha mengubah masyarakat menuju ke arah yang lebih baik seperti yang dicita-citakan. Penyuluhan merupakan suatu usaha menyebar-luaskan hal-hal yang baru agar masyarakat mau tertarik dan berminat untuk melaksanakannya dalam kehidupan mereka seharai-hari.

Selanjutnya Departemen Pertanian RI, (2002) mendefinisikan penyuluhan pertanian adalah pemberdayaan petani dan keluarganya beserta masyarakat pelaku agribisnis melalui kegiatan pendidikan non formal di bidang pertanian agar mereka mampu menolong dirinya sendiri baik di bidang ekonomi, sosial maupun politik sehingga peningkatan pendapatan dan kesejahteraan mereka dapat tercapai. Pendapat senada dikemukakan oleh Soekartawi, (2005: 5) penyuluhan pertanian adalah sistem pendidikan di luar sekolah (informal) yang diberikan kepada petani dan keluarganya dengan maksud agar mereka mampu, sanggup dan berswadaya memperbaiki atau meningkatkan kesejahteraan keluarganya sendiri atau bila memungkinkan mampu meningkatkan kesejahteraan masyarakat di sekelilingnya. 
Kemudian bagi Departemen Pertanian itu sendiri kegiatan penyuluhan mempunyai peranan yang cukup penting karena melalui tenaga penyuluh berbagai informasi baik yang berupa pengetahuan maupun keterampilan yang berkaitan dengan masalah pertanian disampaikan kepada masyarakat terutama pada masyarakat yang tinggal di daerah-daerah peloksok dan daerah terpencil lainnya. Berkaitan dengan hal ini ada beberapa tugas dan peran yang bisa dilakukan tenaga penyuluh pertanian yakni: (1) Memfasilitasi proses pembelajaran petani dan keluarganya beserta masyarakat pelaku agribisnis; (2) Memberikan rekomendasi dan mengihtiarkan akses petani dan keluarganya ke sumber-sumber informasi dan sumberdaya yang akan membantu mereka dalam memecahkan masalah yang dihadapi; (3) Membantu menciptakan iklim usaha yang menguntungkan; (4) Mengembangkan organisasi petani menjadi organisasi sosial ekonomi yang tangguh; (5) Menjadikan kelembagaan penyuluhan sebagai lembaga mediasi dan intermediasi, terutama yang menyangkut teknologi dan kepentingan petani dan keluarganya beserta masyarakat agribisnis.

Dalam menjalankan tugas dan peran tersebut di atas, tenaga penyuluh memerlukan berbagai ketersediaan media komunikasi dan informasi dalam menambah pengetahuan, wawasan serta keterampilan dalam memberikan penyuluhan pada masyarakat petani. Salah satu media komunikasi yang saat ini dibuat dan didistribusikan oleh BPTP dan litbang pertanian diantaranya brosur dan leaflet. Adapun mengenai keberadaan brosur dan leaflet tersebut sudah banyak dimanfaatkan oleh tenaga penyuluh pertanian dalam menyusun program dan meyiapkan materi penyuluhannya.

\section{SIMPULAN}

Hasil penelitian mengenai pemanfaatan media komunikasi dan informasi teknologi pertanian berbentuk brosur dan leaflet dalam menunjang kegiatan penyuluhan pertanian dapat disimpulkan sebagai berikut: Mengenai frekuensi pemanfaatan media komunikasi dan informasi teknologi pertanian yang berupa brosur dan leaflet oleh tenaga penyuluh pertanian tidak terlalu sering, namun demikian para penyuluh tetap menggunakan brosur dan leaflet sebagai salah satu sumber informasi dalam menunjang kegiatan penyuluhan pertanian.

Mengenai intensitas pemanfaatan media komunikasi dan informasi teknologi pertanian berbentuk brosur dan leaflet oleh penyuluh pertanian juga tidak terlalu tinggi, namun sebagian besar tenaga penyuluh memanfaatkan brosur dan leaflet dalam menunjang kegiatan penyuluhan pertanian.

Ada beberapa alasan tenaga penyuluh pertanian menggunakan brosur dan leaflet dalam menunjang kegiatannya antara lain faktor kemutakhiran informasi, keakuratan, serta materinya relevan dengan kebutuhan para penyuluh pertanian.

Kemudian mengenai tujuan penggunaan media komunikasi dan informasi teknologi pertanian yang berupa brosur dan leaflet yaitu untuk menambah pengetahuan dan keterampilan 
tenaga penyuluh pertanian dalam melakukan tugasnya.

\section{DAFTAR PUSTAKA}

Badan Litbang Pertanian. (2004). Panduan Umum Pelaksanaan Pengkajian Serta Program Informasi, Komunikasi dan Diseminasi di BPTP. Jakarta: Badan Litbang Pertanian.

Departemen Pertanian. (2002). Kebijksanaan Nasional Penyelenggaraan Penyuluhan Pertanian. Jakarta: Departemen Pertanian.

Effendi, Onong Uchjana. (1993). Dinamika Komunikasi. Bandung: Remaja Rosdakarya.

Effendi, Onong Uchjana. (1981). Ilmu Komunikasi: Teori dan Praktek. Bandung: Remaja Rosdakarya.

Kushartanti, Ekaningtyas. (2001). Keefektifan Media Cetak pada Diseminasi dan Adopsi Teknologi Jagung Bisma di Kabupaten Semarang. Thesis Program Pasca Sarjana Universitas Gajah Mada. Jogyakarta: Universitas Gajah Mada.

Levis. L, R. (1996). Komunikasi Penyuluhan Pedesaan. Bandung: Citra Aditya Bakti

Mindarti, S. Sukmaya dan Sinaga, A. (2005). Efektifitas Media Cetak dalam Diseminasi Teknologi di Jawa Barat dalam Metoda Diseminasi Teknologi. Bandung: BPTP Jawa Barat. 49 hlm.

Mulyani, E.S, Suryantini, H, dan Setyorini, E. (2006). Persepsi Penyuluh Pertanian terhadap Warta Litbang Pertanian dan Pemanfaatannya. Jurnal Perpustakaan Pertanian 15 (1): 11-17.
Nasution. (1996). Pembangunan, Pengenalan Teori dan Penerapannya. Jakarta: Raja Grafindo Persada.

Paramita, E., Martini, E., Roshetko, J. M., \& Finlayson, R. F. (2013). Media dan metode komunikasi dalam penyuluhan agroforestri: studi kasus di Sulawesi Selatan (Kabupaten Bantaeng dan Bulukumba) dan Sulawesi Tenggara (Kabupaten Konawe dan Kolaka). In Prosiding Seminar Nasional Agroforestri (pp. 488-493).

Pertiwi, P. R., \& Saleh, A. (2010). Persepsi petani tentang saluran komunikasi usahatani padi. Jurnal Komunikasi Pembangunan, 8(2), 4661

Rianto, Yatim. (1996). Metode Penelitian Kependidikan, Surabaya: SIC.

Rogers, Everett M. (1983). Diffusion of Innovation. Canada: The Free Press, A

Soedijanto dan Soehardjan, M. (1999). Petunjuk Teknis Menyusun Tulisan Ilmiah Populer. Jakarta: Badan Litbang Pertanian

Soekartawi, (2005). Prinsip Dasar Komunikasi Pertanian. Jakarta: Universitas Indonesia Stefanie, R. (2013). Respon Pengunjung Terhadap Media Brosur Jatim Park 2. Jurnal EKomunikasi, 1(3), 309-320

Sudiana, D. (1986). Komunikasi Periklanan Cetak. Bandung: Remaja Karya

Sulaiman, Fawzi. (2000). Konsep dan Upaya

Peningkatan Komunikasi dan Diseminasi Hasil litkaji di BPTP Bahan Diskusi. Jakarta: Badan Litbang Pertanian. 20 hlm. Suryantini, Heryati. (2003). Kebutuhan Informasi dan Kebutuhan Kognitif 
Penyuluh Pertanian Serta Hubungannya dengan Penggunaan Sumber Informasi. Jurnal Perpustakaan Pertanian 12 (2): 3341.

Syam, M. dan Widjono, A. (1992). keterkaitan Penelitian dan Penyuluhan, Persepsi, Institusi dan Tata Hubungan Kerja, dalam Teknologi dan Embung, Prosiding Perakitan Teknologi Program Keterkaitan Penelitian Penyuluhan. Jakarta: Badan Litbang Pertanian.
Tjitropranoto, P. (1992). Peningkatan Keterkaitan Penelitian dan Penyuluhan Pertanian dalam Teknologi Konservasi dan Embung. Prosiding Perakitan Teknologi Program Keterkaitan Penelitian dan Penyuluhan Pertanian. Jakarta: Badan Litbang Pertanian.

Tjitropranoto. (1993). Komunikasi Hasil Penelitian dan Umpan Baliknya dalam Prosiding Temu Teknis Komunikasi dan Informasi Hasil-hasil Penelitian Pertanian di Sukamandi. Bogor: Pustaka. 
